\title{
Renal pathology in hematopoietic cell transplant recipients: a contemporary biopsy, nephrectomy, and autopsy series
}

\author{
Brian T Brinkerhoff ${ }^{1}$, Donald C Houghton ${ }^{1}$ and Megan L Troxell ${ }^{1,2}$ \\ ${ }^{1}$ Oregon Health \& Science University, Department of Pathology, Portland, OR, USA and ${ }^{2}$ Oregon Health \& \\ Science University, Knight Cancer Institute, Portland, OR, USA
}

\begin{abstract}
Renal injury in hematopoietic cell transplant recipients may be related to a combination of factors including chemotherapy, radiation, infection, immunosuppressive agents, ischemia, and graft-versus-host disease, and can involve glomerular, tubulointerstitial, and vascular structures. We reviewed renal pathology from 67 patients at a single institution (2009-2014), including 14 patients with biopsy for clinical dysfunction, 6 patients with surgical kidney resection for other causes, and 47 autopsy patients. Kidney specimens frequently contained multiple histopathologic abnormalities. Thrombotic microangiopathy, membranous nephropathy, minimal change disease, and focal segmental glomerulosclerosis were the most common glomerular findings. Pathologies not previously reported in the hematopoietic cell transplant setting included collapsing glomerulopathy, antiglomerular basement membrane disease, fibrillary glomerulonephritis, and in the case of two surgical resections distinctive cellular segmental glomerular lesions that defied classification. Kidney specimens frequently demonstrated acute tubular injury, interstitial fibrosis, arteriolar hyaline, and arteriosclerosis. Other kidney findings at autopsy included leukemia and amyloid (both recurrent), diabetic nephropathy, bacterial infection, fungal invasion, and silver deposition along glomerular and tubular basement membranes. Also in the autopsy cohort, C4d immunohistochemistry demonstrated unexpected membranous nephropathy in two patients, yet $\mathrm{C} 4 \mathrm{~d}$ also colocalized with arteriolar hyaline. This retrospective hematopoietic cell transplant cohort illustrates multifaceted renal injury in patients with renal dysfunction, as well as in patients without clinically recognized kidney injury.
\end{abstract}

Modern Pathology (2016) 29, 637-652; doi:10.1038/modpathol.2016.61; published online 25 March 2016

Hematopoietic cell transplant is a common treatment modality for patients with hematopoietic malignancies as well as other marrow or immune disorders. ${ }^{1,2}$ Treatment protocols are often tailored to the patient's underlying disease as well as health status, with variations including autologous transplant, peripheral blood stem cell transplant, and non-myeloablative transplant. ${ }^{1-4}$ Although some of these current methods of hematopoietic cell transplant tend to be less toxic, many patients still experience significant renal injury because of exposure to a multitude of factors including cytotoxic conditioning agents, radiation, immunosuppression, infection, ischemia, and graft-versus-host disease (GVHD). ${ }^{5-8}$ Acute

Correspondence: Dr ML Troxell, MD, PhD, Department of Pathology, Stanford University Medical Center, L235, 300 Pasteur Drive, Stanford, CA 94305, USA.

E-mail: megant@stanford.edu

Received 27 January 2016; revised 14 February 2016; accepted 15 February 2016; published online 25 March 2016 kidney injury is associated with medications (chemotherapeutic, antibiotic, immunosuppressive), tumor lysis syndrome, renal ischemia, infections, or radiation, whereas chronic kidney injury, including glomerulonephridities, has been associated with chronic GHVD, medications, sequelae of acute injury, ischemia, other comorbidities, and recurrent/secondary malignancy. ${ }^{7-9}$

Numerous descriptive studies, derived from groups of kidney core biopsy specimens from hematopoietic cell transplant recipients with renal dysfunction, have characterized the most common types of glomerulonephritis in hematopoietic cell transplant patients. ${ }^{8,10-18}$ These include membranous nephropathy, minimal change disease, and focal segmental glomerulosclerosis. In addition, acute and chronic thrombotic microangiopathy, or 'transplant-associated thrombotic microangiopathy,' has been shown to occur commonly in hematopoietic cell transplant recipients, $, 8,14,17-25$ with smaller reported numbers of membranoproliferative 
glomerulonephritis, proliferative glomerulonephritis, ANCA-associated glomerulonephritis, and IgA nephropathy. ${ }^{8,18,26-37}$ In studies also examining nonglomerular pathology, kidney specimens also show concomitant tubulointerstitial and vascular changes in hematopoietic cell transplant patients. $8,14,16,19,38,39$ A few single-center studies of autopsy kidney specimen in the hematopoietic cell transplant population have been reported, including one large study focused primarily on thrombotic microangiopathy. ${ }^{20,21,38,40}$

We retrospectively reviewed our single-center experience with renal pathology in specimens from three groups of hematopoietic cell transplant recipients. These included patients with core kidney biopsies for clinical renal dysfunction, in which we characterized three glomerulonephridities not previously reported in the hematopoietic cell transplant population. We also evaluated surgical kidney specimens from hematopoietic cell transplant patients resected for tumor or obstruction, as well as a group of over 40 autopsy kidneys.

\section{Materials and methods}

With IRB approval, Department of Pathology files (2009-2014) were searched for kidney specimens in patients with a history of hematopoietic cell transplant, including renal biopsy specimens, surgical resections, and autopsy cases. One tumor case from 2000 was also included. None of these cases were included in our prior study. ${ }^{16}$ A group of nine consecutive nephrectomies in 2013 for renal cell carcinoma from patients aged 55 years or younger were reviewed as comparative controls for the surgical specimens.

Renal biopsy specimens had been collected and processed using standard procedures for light microscopy (including multiple levels and special stains periodic acid Schiff (PAS), Jones silver, and Trichrome), immunofluorescence microscopy (antibodies to IgG, IgM, IgA, kappa, lambda, C3, $\mathrm{C} 1 \mathrm{q}$, fibrinogen, and, in a few cases, IgG subclasses IgG1, IgG2, IgG3, and IgG4), and electron microscopy as described previously. ${ }^{16,41}$ For surgical resection specimens, in addition to $\mathrm{H} \& \mathrm{E}$ stains, PAS, Jones, and trichrome stains were performed; PAS stains were evaluated for control nephrectomies. For autopsy specimens, an additional PAS stain and C4d immunohistochemistry (described below) was performed on one kidney block per patient. Available light microscopic slides were reviewed with attention to the following parameters: number or percent globally sclerotic glomeruli, glomerular morphology, interstitial inflammation, tubular injury, casts, calcifications, interstitial fibrosis, tubular atrophy, arteriolar and arterial hyaline, and vascular sclerosis.

Immunohistochemical stains were performed in two surgical cases to further characterize glomerular cells using standard immunohistochemical methods on formalin-fixed, paraffin-embedded tissue. CD20, CD3, and CD68 stains were also performed on three control nephrectomies, and C4d immunohistochemical staining was performed on autopsy kidney specimens, as described previously. ${ }^{42}$

In one case with granular non-immune deposits, energy-filtered transmission electron microscopy was performed. Energy-filtered transmission electron microscopy imaging was acquired on a Titan Krios (FEI, Hillsboro, OR, USA) at $300 \mathrm{keV}$, with a Gatan 963 Quantum GIF. Images were acquired on a postGIF Gatan US4000 CCD. Energy-filtered transmission electron microscopy imaging was achieved using the three-image method. Briefly, three images are acquired at pre- and post-M-N edges, and then background images are subtracted to show the signal from the element of interest (in this case silver).

Clinical data was abstracted from the electronic medical record as available, including clinical renal diagnosis, baseline and current serum creatinine, urinalysis (proteinuria, hematuria), serologies (antinuclear antibody, ANCA, antiglomerular basement membrane, complement C3, C4), viral status (polyomavirus BK, cytomegalovirus, hepatitis), along with treatment and outcome data after kidney biopsy. Hematopoietic cell transplant parameters such as time post-transplant, original disease requiring hematopoietic cell transplant, type of transplant (autologous, allogeneic; marrow, peripheral stem cells, or cord blood), conditioning regimen and prior chemotherapy where available, GVHD history, and prophylaxis/treatment. Statistical analysis was performed with Statview program, or an online calculator (www.socscistatistics.com), using unpaired $T$-test, $\chi^{2}$ test, or Fisher's exact test. $P$-value of 0.05 was considered significant.

\section{Results}

To examine kidney pathology in the setting of hematopoietic cell transplant, we reviewed our institutional experience (2009-2014) with histopathologic specimens in the following settings: renal biopsies performed for kidney dysfunction $(n=16$ biopsies in 14 patients); resection specimens performed for renal cell carcinoma or obstruction $(n=6)$; and autopsy $(n=47)$; each group is described separately below.

\section{Renal Biopsies for Kidney Dysfunction}

Over a 5-year time period, we received 16 kidney biopsies for renal dysfunction from 14 patients (Tables 1A and 1B and Supplementary Table 1). Patients' ages ranged from 8 to 76 years at the time of biopsy, and the time since transplant ranged from 1 month to 21 years. The principal biopsy findings were acute or chronic thrombotic microangiopathy in five patients, minimal change disease $(n=2)$, focal 


\begin{tabular}{|c|c|c|c|c|c|c|c|c|c|c|c|}
\hline Case & $\begin{array}{l}\text { Age/ } \\
\text { sex }\end{array}$ & Pretransplant diagnosis & $\begin{array}{l}\text { Cells and } \\
\text { donor }\end{array}$ & $\begin{array}{l}\text { Preparative } \\
\text { regimen }\end{array}$ & $\begin{array}{l}\text { Calcineurin } \\
\text { inhibitor } \\
\text { exposure }\end{array}$ & $\begin{array}{l}\text { Prior graft- } \\
\text { versus-host } \\
\text { disease }\end{array}$ & $\begin{array}{l}\text { Biopsy time after } \\
\text { transplant } \\
\text { (years) }\end{array}$ & $\begin{array}{c}s C r \\
(m g / d l)\end{array}$ & $U P r$ & Treatment & Follow-up \\
\hline 1 & $59 / \mathrm{F}$ & $\begin{array}{l}\text { Acute lymphoblastic } \\
\text { leukemia /lymphoma }\end{array}$ & Allo-BMT & TBI, cytoxan & Yes & GI & 3 & 1.4 & Ratio: 11 & $\begin{array}{l}\text { None; hip infection } \\
\text { resolving }\end{array}$ & $\begin{array}{l}\text { Improved } \\
\text { proteinuria }\end{array}$ \\
\hline 2 & $8 / \mathrm{F}$ & $\begin{array}{l}\text { Acute lymphoblastic } \\
\text { leukemia /lymphoma }\end{array}$ & Allo-PBSCT & TBI & No & Skin, liver & 0.83 & 2.0 & Ratio: 12 & None & $\begin{array}{l}\text { Died } 4 \text { days after } \\
\text { biopsy }\end{array}$ \\
\hline 3 & $13 / \mathrm{M}$ & Acute myeloid leukemia & Allo-UBT & $\begin{array}{l}\text { TBI, cytoxan, } \\
\text { fludarabine }\end{array}$ & Yes & Skin, GI & 0.08 & 2.2 & N/A & None & Improved sCr \\
\hline 3 & $14 / \mathrm{M}$ & Same & Same & Same & Same & Same & 0.92 & 2.0 & $2+$ & None & ESRD \\
\hline 4 & $53 / \mathrm{F}$ & Myelodysplastic syndrome & Allo-PBSCT & $\begin{array}{l}\text { Fludarabine, } \\
\text { melphalan }\end{array}$ & Yes & Skin & 1.5 & 2.1 & N/A & N/A & N/A \\
\hline 5 & $56 / F$ & Large B-cell lymphoma & Allo-UBT & $\begin{array}{l}\text { TBI, cytoxan, } \\
\text { fludarabine }\end{array}$ & Yes & Joint & 1.1 & 2.6 & $2.4 \mathrm{~g}$ per day & Eculizumab & No change \\
\hline 6 & $58 / \mathrm{M}$ & Acute myeloid leukemia & Allo-BMT & $\begin{array}{l}\text { Cytarabine, } \\
\text { daunomycin }\end{array}$ & $\mathrm{n} / \mathrm{a}$ & Skin & 21 & 2.4 & N/A & ACE; d/c metformin & Worsening sCr \\
\hline 7 & $23 / \mathrm{M}$ & Blackfan-Diamond anemia & Allo-PBSCT & $\begin{array}{l}\text { Cytoxan, } \\
\text { fludarabine, } \\
\text { capecitabine }\end{array}$ & Yes & Lung, GI & 8 & 2.7 & Ratio: 1.9 & Linsinopril & ESRD, transplant \\
\hline 8 & $16 / \mathrm{M}$ & $\begin{array}{l}\text { Chronic granulomatous } \\
\text { disease (Caucasian) }\end{array}$ & Allo-BMT & TBI, fludarabine & Yes & GI & 1 & 0.9 & Ratio: 37 & $\begin{array}{l}\text { Steroid, sirolimus, } \\
\text { rituximab }\end{array}$ & $\begin{array}{l}\text { Nephrotic syndrome } \\
\text { remits for } 2 \text { years }\end{array}$ \\
\hline 8 & $18 / \mathrm{M}$ & Same & Same & Same & Same & Same & 3.2 & 0.5 & Ratio: 2.6 & $\begin{array}{l}\text { Plasmapheresis, } \\
\text { rituximab, tacrolimus } \\
\text { prednisone }\end{array}$ & $\begin{array}{l}\text { Died } 2 \text { months after } \\
\text { biopsy }\end{array}$ \\
\hline 9 & $76 / \mathrm{M}$ & Acute myeloid leukemia & Allo-BMT & $\begin{array}{l}\text { TBI, busulfan, } \\
\text { fludarabine }\end{array}$ & Yes & Skin, GI & 1.5 & 1.9 & Ratio: 4.7 & Prednisone & Improved sCr; UPr \\
\hline 10 & $43 / \mathrm{F}$ & Acute myeloid leukemia & Allo-UBT & Cytarabine & Yes & Yes & 0.83 & 2.7 & 'Marked' & N/A & N/A \\
\hline 11 & $71 / \mathrm{M}$ & Myeloma & Auto-BMT & N/A & N/A & N/a & 5.5 & 1.7 & N/A & Prednisone; imuran & Improved sCr; UPr \\
\hline 12 & 73/M & Myelodysplastic syndrome & Allo-BMT & N/A & N/A & Yes & 10 & 6.5 & N/A & None & ESRD \\
\hline 13 & $24 / \mathrm{M}$ & Hodgkin lymphoma & Auto-PBSCT & BEAM & No & No & 1.5 & 2.0 & $7 \mathrm{~g}$ per day & Rituximab & $\begin{array}{l}\text { Improved sCr and } \\
\text { UPr }\end{array}$ \\
\hline 14 & $58 / \mathrm{M}$ & Light-chain amyloid & Auto-PBSCT & Melphalan & No & No & 6 & 1.6 & 8.5 g per day & $\begin{array}{l}\text { Velcade; } \\
\text { dexamethasone }\end{array}$ & No change \\
\hline
\end{tabular}

Abbreviations: ACE, angiotensin-converting enzyme; Allo, allogeneic; AML, acute myeloid leukemia; Auto, autologous; BEAM, carmustine, etoposide, cytarabine, and melphalan; BMT, bone marrow stem cell transplant; chemo, cytotoxic chemotherapy (unknown type); cytoxan, cyclophosphamide; ESRD, end-stage renal disease; GI, gastrointestinal tract; MTX, methotrexate; N/A, not available PBSCT, peripheral blood stem cell transplant; ratio, urine protein to urine creatinine ratio (mg/mg); sCr, serum creatinine; TBI, total body irradiation; UBT, umbilical cord blood stem cell transplant; UPr, urine protein. 
Table 1B Biopsy Pathology

\begin{tabular}{|c|c|c|c|c|c|c|}
\hline Case & Principal biopsy diagnoses & $\begin{array}{l}\% \text { Global } \\
\text { glomerulosclerosis }\end{array}$ & $\begin{array}{l}\text { \% Interstitial fibrosis/ } \\
\text { tubular atrophy }\end{array}$ & Interstitial inflammation & $\begin{array}{l}\text { Arteriolar } \\
\text { hyaline }\end{array}$ & Arteriosclerosis \\
\hline 1 & $\begin{array}{l}\text { Chronic thrombotic microangiopathy } \\
\text { Segmental immune deposits }\end{array}$ & 7 & $20 / 25$ & Minimal mononuclear & Marked & Moderate \\
\hline 2 & Acute thrombotic microangiopathy & 0 & $\mathrm{~N} / \mathrm{A}^{\mathrm{a}}$ & None & None & None \\
\hline 3 & Acute tubular injury & 0 & $30 / 30$ & None & None & None \\
\hline 3 & $\begin{array}{l}\text { Acute and chronic thrombotic } \\
\text { microangiopathy } \\
\text { Acute tubular injury }\end{array}$ & 0 & $\mathrm{~N} / \mathrm{A}^{\mathrm{a}}$ & None & None & $\mathrm{N} / \mathrm{A}^{\mathrm{a}}$ \\
\hline 4 & $\begin{array}{l}\text { Acute and chronic thrombotic } \\
\text { microangiopathy } \\
\text { Interstitial nephritis }\end{array}$ & 23 & $50 / 50$ & Moderate with eosinophils & Focal & Mild \\
\hline 5 & $\begin{array}{l}\text { Acute and chronic thrombotic } \\
\text { microangiopathy } \\
\text { Segmental immune deposits } \\
\text { Acute tubular injury }\end{array}$ & 0 & $10 / 50$ & None & Focal & Moderate \\
\hline 6 & $\begin{array}{l}\text { Focal segmental glomerulosclerosis; diabetic } \\
\text { nephropathy }\end{array}$ & 25 & $30 / 30$ & Mild & Marked & Moderate \\
\hline 7 & Focal segmental glomerulosclerosis; & 21 & $70 / 70$ & Moderate, in fibrosis & Marked & Moderate \\
\hline 8 & $\begin{array}{l}\text { Collapsing glomerulopathy } \\
\text { Acute tubular injury }\end{array}$ & 10 & $0 / 0$ & None & Focal & Focal, mild \\
\hline 8 & Focal segmental glomerulosclerosis; & 39 & $20 / 20$ & Moderate, in fibrosis & None & Mild \\
\hline 9 & $\begin{array}{l}\text { Minimal change disease } \\
\text { Acute tubular injury }\end{array}$ & 15 & $20 / 25$ & None & Focal & Mild \\
\hline 10 & $\begin{array}{l}\text { Minimal change disease } \\
\text { Acute interstitial nephritis } \\
\text { Acute tubular injury }\end{array}$ & 0 & $0 / 0$ & Moderate with eosinophils & None & None \\
\hline 11 & $\begin{array}{l}\text { Acute and chronic interstitial nephritis } \\
\text { Podocyte effacement }(\sim 70 \%)\end{array}$ & 29 & $40 / 40$ & $\begin{array}{l}\text { Moderate lymphoplasmacytic with } \\
\text { eosinophils }\end{array}$ & Focal & Mild \\
\hline 12 & Antiglomerular basement membrane disease & 55 & $80 / 90$ & Moderate, mixed with tubulitis & None & Moderate \\
\hline 13 & Fibrillary glomerulonephritis & 5 & $5 / 5$ & Patchy mild & None & Mild \\
\hline 14 & Amyloid & 46 & $50 / 90$ & Focal & None & None \\
\hline
\end{tabular}

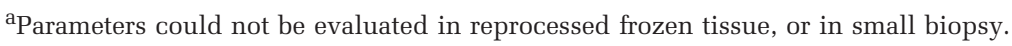


segmental glomerulosclerosis $(n=3)$, collapsing glomerulopathy $(n=1)$, antiglomerular basement membrane disease $(n=1)$, fibrillary glomerulonephritis $(n=1)$, amyloidosis ( $n=1$, presumably recurrent), interstitial nephritis $(n=1)$, and acute tubular injury $(n=1)$. Biopsies frequently contained multiple histopathologic abnormalities, including acute tubular injury/necrosis, arteriolar hyalinosis, global glomerulosclerosis, interstitial fibrosis/tubular atrophy, and interstitial inflammation. Two thrombotic microangiopathy cases also demonstrated segmental subepithelial or intramembranous immune deposits (Table 1B and Figures 1a-C). To our knowledge, collapsing glomerulopathy, antiglomerular basement membrane disease, and fibrillary glomerulonephritis have not been previously reported in hematopoietic cell transplant patients, and these cases are described in greater detail below.

Collapsing glomerulopathy. Patient no. 8 received an allogenic bone marrow transplant for chronic granulomatous disease at the age of 15 years, with fludaribine and total body irradiation conditioning. He was of Caucasian race, had biopsy-proven GVHD of the colon, and had cyclosporine exposure. One year after transplant he presented with nephrotic syndrome with a urine protein to creatinine ratio of $37 \mathrm{mg} / \mathrm{mg}$, low serum albumin of $1 \mathrm{~g} / \mathrm{dl}$, and a serum creatinine of $0.9 \mathrm{mg} / \mathrm{dl}$, elevated from baseline of $0.6 \mathrm{mg} / \mathrm{dl}$. Renal biopsy demonstrated collapsing glomerulopathy involving 2 of 10 glomeruli sampled for light microscopy (Figure 1d), and an additional involved glomerulus was seen in the electron microscopy specimen, which demonstrated diffuse podocyte foot process effacement and glomerular basement membrane collapse; no tubuloreticular structures were identified (Figures 1e and f). Immunofluorescence studies were negative, and immunohistochemical stains were negative for parvovirus, adenovirus, and polyoma virus. There was evidence of tubular injury, with vesicular tubular cytoplasmic change and mitotic figures, but there was no tubular atrophy or interstitial fibrosis. Despite the patient's young age, mild-to-moderate arteriosclerosis was present. Arteriolar hyalinosis was also noted.

The patient was treated with steroids, sirolimus, and rituximab, which resulted in sustained clinical resolution of the nephrotic syndrome for 2 years. Then, his urine protein to creatinine ratio increased from 0.5 to 5 , with stable serum creatinine of $0.5 \mathrm{mg} / \mathrm{dl}$, and he was rebiopsied. This biopsy demonstrated focal segmental glomerulosclerosis of no special type, along with nearly $40 \%$ global glomerulosclerosis and increased interstitial fibrosis and tubular atrophy (Table 1B).

Anti-GBM disease. Patient no. 12 received an allogenic bone marrow transplant for myelodysplastic syndrome at the age of 63 years (unknown conditioning and prior chemotherapy); he had history of clinical GVHD (lung), but never smoked.
Ten years after transplant he presented with rapidly rising serum creatinine (up to $6.5 \mathrm{mg} / \mathrm{dl}$ over 10 days). The renal biopsy showed 10 globally sclerotic glomeruli of 18 sampled. Seven of the remaining glomeruli contained cellular crescents (Figures 1g-i). Interstitial inflammation was brisk, and tubulitis was present. There was $80-90 \%$ interstitial fibrosis and tubular atrophy, with moderate arteriosclerosis. Immunofluorescence demonstrated diagnostic IgG linear glomerular basement membrane staining of $2-3+$ intensity (Figure 1i), along with linear IgG1, $\kappa$, and $\lambda$. Fibrinogen stained five glomeruli segmentally. Electron microscopy showed thick glomerular basement membranes $(500 \mathrm{~nm})$, podocyte foot process effacement, but no deposits. After biopsy, serum antiglomerular basement membrane studies returned positive (reported as 66 , reference range: negative $<19 \mathrm{AU} / \mathrm{ml}$; positive $26 \mathrm{AU} / \mathrm{ml}$ ); and weakly positive antimyeloperoxidase. The patient was started on hemodialysis, and passed away 18 months later.

Fibrillary glomerulonephritis. Patient no. 13 had Hodgkin lymphoma, with proteinuria noted during prior lymphoma relapse, although he had no kidney biopsy before hematopoietic cell transplant. He received an autologous peripheral blood stem cell transplant at the age of 23 years with BEAM conditioning (carmustine, etoposide, cytarabine, melphalan), after previous chemotherapy regimens. Eighteen months after transplant, elevated serum creatinine $(2 \mathrm{mg} / \mathrm{dl}$ ) and proteinuria was noted (urine protein to creatinine ratio of $\sim 6$ ). The renal biopsy demonstrated a proliferative glomerulonephritis with crescents, glomerular basement membrane irregularities, and deposit (Figures 1j-1).

Immunofluorescence was positive with smudgy staining for IgG, IgG1, $\kappa, \lambda$, and C3. Electron microscopy revealed fibrillary deposits with 20-30 $\mu \mathrm{m}$ fibril diameter in mesangial zones and along glomerular basement membranes. Interstitial fibrosis and tubular atrophy were minimal, and arteriosclerosis was mild. The patient was treated with rituximab, with partial renal remission (proteinuria decreased to urine protein to creatinine ratio of $2 \mathrm{mg} / \mathrm{mg}$, serum creatinine $<1 \mathrm{mg} / \mathrm{dl}$ ) 1 year after biopsy, without evidence of lymphoma recurrence.

\section{Kidney Resection Specimens}

Five hematopoietic cell transplant recipients with renal cell carcinoma and one patient with ureteral stricture (ureteral injury during retroperitoneal lymph node dissection) underwent surgical resection (three nephrectomy, three partial nephrectomy) 6 to 23 years after transplant (average 15.7 years; Table 2 and Supplementary Table 1), markedly longer than the biopsy group. Non-neoplastic renal disease was neither recognized nor clinically investigated in any of the patients with carcinoma before 
surgery. In the renal cell carcinoma patients, global glomerulosclerosis was variable, and interstitial fibrosis and tubular atrophy was relatively modest, yet vascular changes were striking (Table 2). All five renal cell carcinoma patients had arteriolar hyalinosis (extensive in four specimens), and all
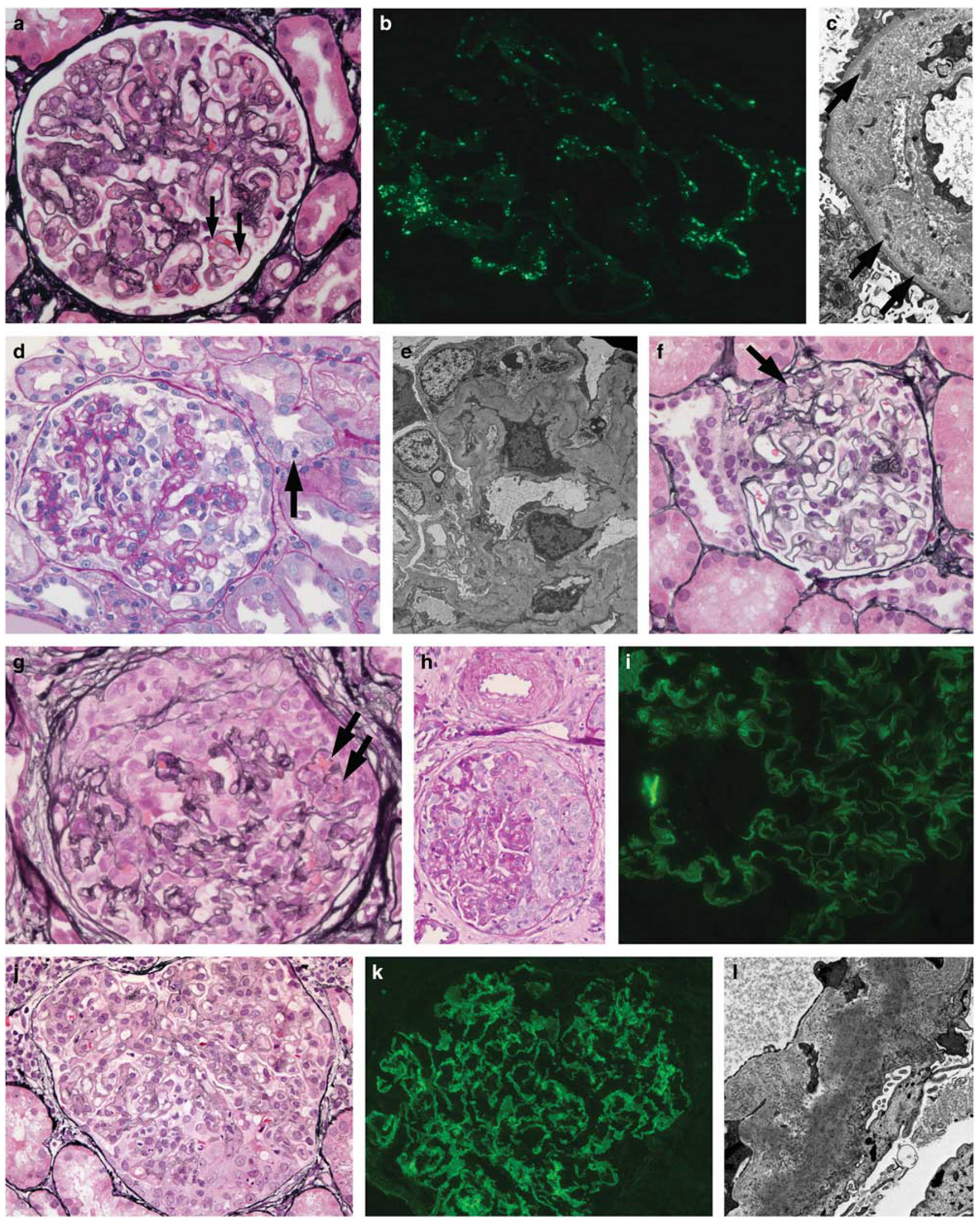
had arteriosclerosis (two mild, three moderate), despite their young age (23-63 years, average 44.4 years). Comparison with control nephrectomies from nine non-hematopoietic cell transplant patients under the age of 55 years with renal cell carcinoma is shown in Table 2.

In glomeruli, all five of the hematopoietic cell transplant patients with renal cell carcinoma had mild segmental mesangial sclerosis or segmental basement membrane duplication (Table 2). Interestingly, two patients (nos. 16 and 17) had distinctive but difficult to characterize segmental cellular glomerular lesions (Figures 2a-c) involving 10\% of glomeruli, and not recognized at the time of initial pathologic evaluation. Patient no. 17 had spot proteinuria of $>300 \mathrm{mg} / \mathrm{dl}$, but proteinuria was not measured in any other patients. The involved segments were expanded by confluent collections of cells with clear cytoplasm and bland nuclei without nucleoli; the underlying glomerular architecture was effaced. There were PAS+ droplets within the epithelioid cells, with intercellular basement membrane material in these segments seen by PAS, Jones, and Trichrome stains.

Immunohistochemical studies were performed to further characterize the intraglomerular cells (Table 2 and Figures 2d-f); markers for monocyte/ macrophages (CD68) and mesangial cells (GATA3) were positive in a subset of the cells, whereas endothelial markers (CD31, ERG) stained mostly the periphery of these segments (Table 3). Lack of staining for PAX2 and CD10 disfavored intraglomerular renal cell carcinoma. Tissue was punched from the formalin-fixed, paraffin-embedded archival blocks and reprocessed for electron microscopy, which demonstrated basement membrane investing large cells, some but not all of which had ultrastructural features suggestive of histiocytes.

Glomeruli in patient nos. 16 and 17 without those segmental lesions were slightly hypercellular and also appeared to contain prominent mononuclear leukocytes in capillary loops, which were further characterized by immunostaining for CD20, CD3, and CD68, in comparison with three control nephrectomy specimens (Table 4). As cell counts were similar in transplant and non-transplant nephrectomies, glomerulitis is likely secondary to the surgical procedure or specimen handling.

\section{Renal Pathology in Hematopoietic Cell Transplant Patients at Autopsy}

Forty-seven hematopoietic cell transplant recipients underwent autopsy at our center over the 5-year study period. Patients' ages were 1-71 years at autopsy (average 50.3 years). Post-transplant survival ranged from 1 day to 25 years (average 13 months), with 32 patients (68\%) deceased within 6 months of transplantation (Table 5). Pulmonary disease, including infection, contributed to death in 39 patients (83\%); only one patient had leukemia relapse, and another had amyloid at the time of death. Patient and transplantation parameters were widely varied, and are summarized in Table 4, with data for each patient tabulated in the Supplementary Data section.

The most prevalent glomerular finding in the autopsy cohort was acute thrombotic microangiopathy, seen in 10 patients (21\%; five female and five male recipients). Each of these patients received allogeneic stem cells, six were conditioned with total body irradiation, and at least eight had calcineurin inhibitor exposure after transplantation. Patients survived an average of 5.8 months after hematopoietic cell transplant (range 1 month-2 years, with 8 of 10 surviving 6 months or less). In patients with thrombotic microangiopathy, serum creatinine ranged from 0.34 to $2.2 \mathrm{mg} / \mathrm{dl}$ and averaged $0.9 \mathrm{mg} / \mathrm{dl}$ before death. Cause of death in thrombotic microangiopathy patients included acute lung injury/ diffuse alveolar damage in six patients (some with pulmonary hemorrhage), systemic or pulmonary fungal infection (1-aspergillus, 1-zygomycoses), hemosiderosis, and cerebral infarct with subarachnoid and pulmonary hemorrhage. Glomerular microangiopathic changes were generally seen within only a small fraction of glomeruli and included capillary loops occluded by pale flocculent material, often accompanied by fragmented red blood cells, and occasionally by fibrin in H\&E-stained sections (similar to Figure 1a); however, autolysis may have

Figure 1 Renal biopsy findings in patients with renal dysfunction. (a-c) Thrombotic microangiopathy, patient no. 5a. Silver stain demonstrates glomerular basement membrane (GBM) duplication (chronic thrombotic microangiopathic change), whereas endothelial cell swelling and red blood cell fragments (arrows) indicate acute thrombotic microangiopathy. (b) Immunoglobulin A (IgA) immunofluorescence shows discrete granular deposits along glomerular capillary loops. (c) Electron microscopy shows multilayer GBM with electron-dense deposits (arrows show some of the deposits). (d-f) Collapsing glomerulopathy, patient no. 8. (d) Periodic acid Schiff (PAS) stain shows collapse of the glomerular tuft and hyperplastic podocytes, especially in the rightmost aspect of the glomerulus. Surrounding tubules show injury with sloughed epithelial cells and mitotic figure (arrow). (e) Electron microscopy with collapsing basement membranes and diffuse podocyte foot process effacement. (f) Subsequent biopsy from 2 years later demonstrates focal segmental glomerulosclerosis of no special type, with hyaline (arrow). (g-i) Anti-GBM disease, patient no. 12. (g) Silver stain shows large cellular crescent, with GBM breaks and fibrin (arrows). (h) PAS stain shows cellular crescent; the artery above demonstrates intimal fibrosis (arteriosclerosis). (i) Immunofluorescence demonstrates linear IgG staining. (j-l) Fibrillary glomerulonephritis, patient 13. (j) A small cellular crescent is seen at the lower aspect of the glomerulus; there is pink deposit toward the upper aspect of the glomerulus on Jones silver stain with H\&E counterstain. (k) Immunofluorescence staining for IgG shows smudgy capillary loop and mesangial staining. (l) Electron microscopy with randomly oriented fibrils of 20-30 nm diameter. Original magnifications: 200x (h); 400x (a, b, d, f, g, and i-k); 3710x (e); 14 000x (c); 21 800x i. 
Table 2 Nephrectomy Cohort: Clinical Parameters and Pathologic Findings

\begin{tabular}{|c|c|c|c|c|c|c|c|c|c|}
\hline Case & $\begin{array}{c}\text { Age } \\
\text { (years) }\end{array}$ & Tumor & $\begin{array}{c}\% \text { Global } \\
\text { glomerulosclerosis }\end{array}$ & $\begin{array}{l}\% \text { Interstitial fibrosis/ } \\
\text { tubular atrophy }\end{array}$ & $\begin{array}{l}\text { Arteriolar } \\
\text { hyaline }\end{array}$ & Arteriosclerosis & Other pathology & History & $\begin{array}{c}s C r \\
(m g / d l)\end{array}$ \\
\hline 15 & 53 & None; obstructed & 33 & 20 & None & Moderate & $\begin{array}{l}\text { Hydronephrosis (ureteral } \\
\text { obstruction), glomerulomegaly, } \\
\text { calcification }\end{array}$ & $\begin{array}{l}\text { Tandem auto-HCT } 13 \text { years } \\
\text { prior for seminoma }\end{array}$ & 1.4 \\
\hline 16 & 23 & $\begin{array}{l}\text { Renal cell carcinoma, clear } \\
\text { cell, grade } 2,3.8 \mathrm{~cm}\end{array}$ & 45 & 10 & Marked & Mild & $\begin{array}{l}\text { Segmental cellular glomerular } \\
\text { lesions in } \sim 8 \% \text {, }\end{array}$ & $\begin{array}{l}\text { Allo-PBSCT } 11 \text { years priora for } \\
\text { AML with TBI and cytoxan }\end{array}$ & 0.9 \\
\hline 17 & 40 & $\begin{array}{l}\text { Renal cell carcinoma, clear } \\
\text { cell, grade } 3,6 \mathrm{~cm}\end{array}$ & 10 & $<5$ & Marked & Moderate & $\begin{array}{l}\text { Segmental cellular glomerular } \\
\text { lesions in } \sim 10 \% \text {, }\end{array}$ & $\begin{array}{l}\text { Allo-BMT } 22 \text { years prior for } \\
\text { ALL with TBI and chemo }\end{array}$ & 1.2 \\
\hline 18 & 51 & $\begin{array}{l}\text { Renal cell carcinoma, clear } \\
\text { cell, grade } 2,2.5 \mathrm{~cm}\end{array}$ & 15 & 10 & Focal & Moderate & $\begin{array}{l}\text { Mild mesangial sclerosis, JGA } \\
\text { hyperplasia }\end{array}$ & $\begin{array}{l}\text { Allo-BMT } 6 \text { years prior for } \\
\text { AML with TBI }\end{array}$ & $\mathrm{n} / \mathrm{a}$ \\
\hline 19 & 45 & $\begin{array}{l}\text { Renal cell carcinoma, } \\
\text { papillary, grade } 2,10 \mathrm{~cm}\end{array}$ & $<5$ & $<5$ & Focal & Mild & $\begin{array}{l}\text { Mild mesangial sclerosis, rare } \\
\text { GBM duplication, } \\
\text { glomerulomegaly }\end{array}$ & $\begin{array}{l}\text { Allo-BMT } 19 \text { years prior for } \\
\text { CML with TBI and cytoxan }\end{array}$ & 1.7 \\
\hline 20 & 63 & $\begin{array}{l}\text { Renal cell carcinoma, } \\
\text { papillary, grade } 2,1.8 \mathrm{~cm}\end{array}$ & 50 & 60 & Marked & Moderate & $\begin{array}{l}\text { Mesangial sclerosis and } \\
\text { segmental GBM duplication, } \\
\text { calcification }\end{array}$ & $\begin{array}{l}\text { Allo-HCT } 23 \text { years prior for } \\
\text { CML with TBI, cytoxan and } \\
\text { MTX }\end{array}$ & 1.7 \\
\hline HCT Average & & 45.8 & 26 & 18 & $\begin{array}{l}\text { Present in } 5 / 6 \\
\text { Marked in } 3 / 6\end{array}$ & $\begin{array}{l}\text { Present in } 6 / 6 \\
\text { Moderate in } 4 / 6\end{array}$ & & & \\
\hline Control case & $\begin{array}{c}\text { Age } \\
\text { (years) }\end{array}$ & Tumor & $\begin{array}{c}\% \text { Global } \\
\text { glomerulosclerosis }\end{array}$ & $\begin{array}{l}\text { \% Interstitial fibrosis/ } \\
\text { tubular atrophy }\end{array}$ & $\begin{array}{l}\text { Arteriolar } \\
\text { hyaline }\end{array}$ & Arteriosclerosis & Other pathology & History & \\
\hline C1 & 55 & $\begin{array}{l}\text { Renal cell carcinoma, clear } \\
\text { cell, grade } 1,5.6 \mathrm{~cm}\end{array}$ & $<2$ & $<2$ & No & Moderate & & Hypertension & 0.7 \\
\hline $\mathrm{C} 2$ & 52 & $\begin{array}{l}\text { Renal cell carcinoma, clear } \\
\text { cell, grade } 3,7.5 \mathrm{~cm}\end{array}$ & $<2$ & 5 & Focal arterial & Moderate & $\begin{array}{l}\text { Juxtaglomerular apparatus } \\
\text { hyperplasia }\end{array}$ & Diabetes, hypertension & 0.8 \\
\hline C3 & 45 & $\begin{array}{l}\text { Renal cell carcinoma, clear } \\
\text { cell, grade } 3,7 \mathrm{~cm}\end{array}$ & $<5$ & 10 & No & Mild & Glomerulomegaly & Diabetes, hypertension & 1.5 \\
\hline $\mathrm{C} 4$ & 54 & $\begin{array}{l}\text { Renal cell carcinoma, clear } \\
\text { cell, grade } 3,6.5 \mathrm{~cm}\end{array}$ & $<5$ & 5 & Moderate & Mild & Glomerulomegaly & $\begin{array}{l}\text { Diabetes, hypertension lung } \\
\text { cancer w/ chemotherapy }\end{array}$ & 0.6 \\
\hline C5 & 43 & $\begin{array}{l}\text { Renal cell carcinoma, clear } \\
\text { cell, grade } 3,16 \mathrm{~cm}\end{array}$ & $<2$ & 20 & Yes & Mild & Interstitial inflammation & & 1.4 \\
\hline C6 & 45 & Oncocytoma, $4.5 \mathrm{~cm}$ & $<2$ & $<2$ & No & Mild & Glomerulomegaly & & 1.1 \\
\hline C7 & 43 & $\begin{array}{l}\text { Renal cell carcinoma, clear } \\
\text { cell, grade } 3,10.5 \mathrm{~cm}\end{array}$ & $<5$ & $<2$ & Focal & Mild & & & 1.2 \\
\hline C8 & 45 & $\begin{array}{l}\text { Renal cell carcinoma, clear } \\
\text { cell, grade } 3,6.5 \mathrm{~cm}\end{array}$ & $<2$ & $<2$ & Focal & Mild & & & 1.9 \\
\hline C9 & 55 & $\begin{array}{l}\text { Urothelial carcinoma, high } \\
\text { grade, } 8.5 \mathrm{~cm} \text {; obstructed }\end{array}$ & $<5$ & 90 & Moderate & Mild & Interstitial inflammation & Diabetes_diet controlled & 1.0 \\
\hline $\begin{array}{l}\text { Control } \\
\text { average }\end{array}$ & 48.5 & & $<3$ & 15 & $\begin{array}{l}\text { Present in } 6 / 9 \\
\text { Marked in } 0 / 9\end{array}$ & $\begin{array}{l}\text { Present in } 9 / 9 \\
\text { Moderate in } 2 / 9\end{array}$ & & & \\
\hline
\end{tabular}

Abbreviations: ALL, acute lymphoblastic leukemia/lymphoma; Allo, allogeneic; AML, acute myeloid leukemia; Auto, autologous; BMT, bone marrow stem cell transplant; chemo, cytotoxic chemotherapy (unknown type); cytoxan, cyclophosphamide; GBM, glomerular basement membrane; HCT, hematopoietic cell transplant; MTX, methotrexate; PBSCT, peripheral blood stem cell transplant; TBI, total body irradiation.

${ }^{a}$ Donor cell infusion 5 years prior. 

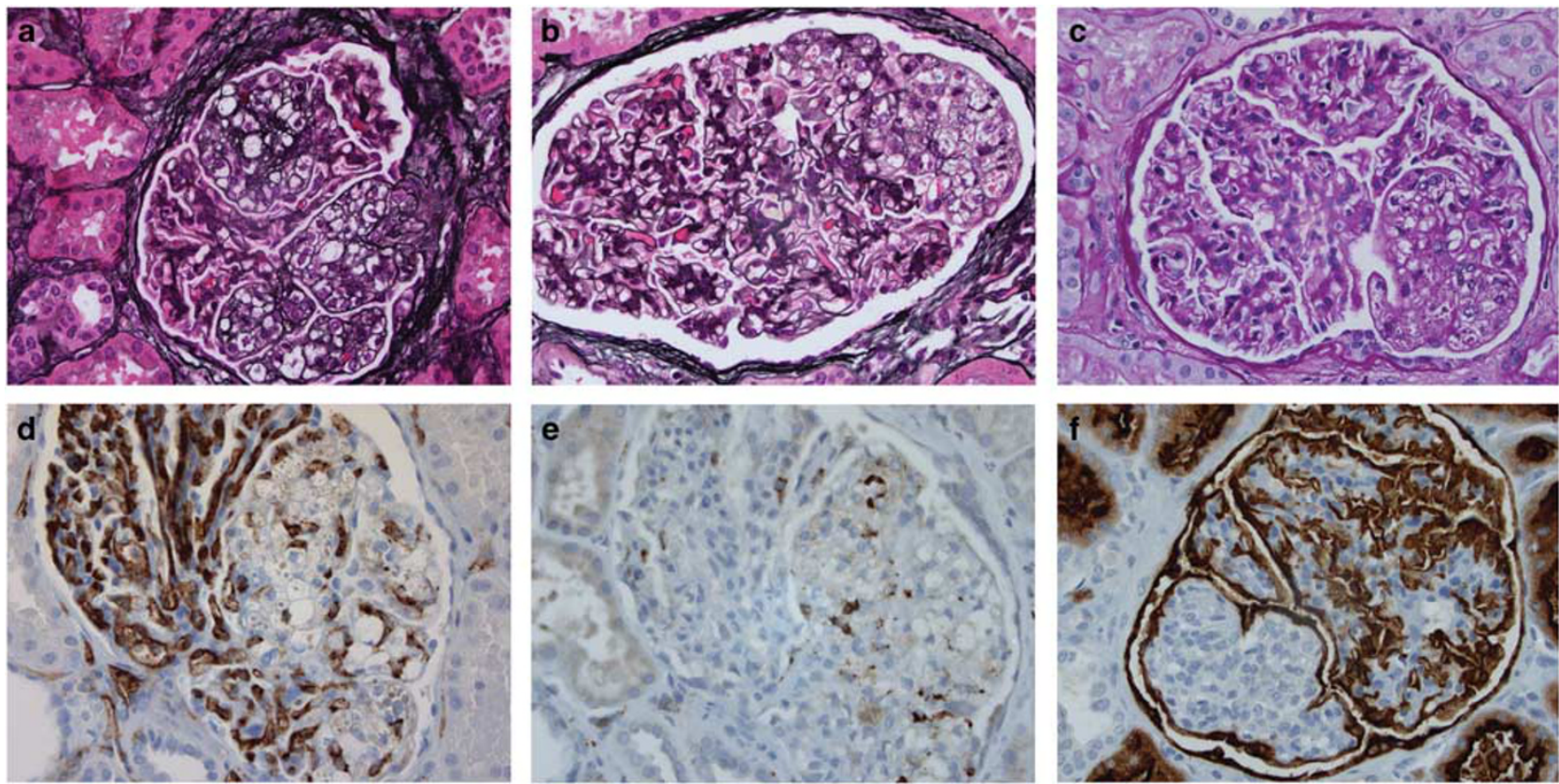

Figure 2 Unusual segmental glomerular lesions in hematopoietic cell transplant patients with renal cell carcinoma. (a) Hypercellular segments occupy much of this glomerular profile and are characterized by cells with clear cytoplasm and central nuclei, with few patent capillary loops on Jones silver stain. (b) A cellular lesion is present in the rightmost portion of the glomerulus; and many cells contain prominent eosinophilic cytoplasmic droplets on Jones stain. (c) PAS stain shows cellular lesion in the bottom right portion of the glomerulus. (d) CD31 stain highlights endothelial cells in the normal portions of the glomerulus, but only stains a subset of cells in the involved segment at right. (e) CD68 stain identifies only a subset of cells as macrophages within the involved segment (serial section and matched field with (d)). (f) CD10 demonstrates podocytes outlining the cellular segment at bottom left. These lesions were negative for another renal cell carcinoma marker PAX2 (not shown). Orginal magnifications: 400x (a-f), all patient no. 16.

Table 3 Immunohistochemical Typing of Segmental Glomerular Lesions, with Antibody Reagents

\begin{tabular}{|c|c|c|c|c|}
\hline Stain & Antigen distribution & $\begin{array}{l}\text { Results in segmental glomerular } \\
\text { lesions }\end{array}$ & Clone & Source \\
\hline PAX2 & $\begin{array}{l}\text { Distal tubules, parietal epithelium (nuclear), } \\
\text { renal cell carcinoma }\end{array}$ & Negative & Polyclonal & Invitrogen \\
\hline CD10 & Podocytes, proximal tubules, renal cell carcinoma & Negative (peripheral podocytes only) & $56 C 6$ & Cell Marque \\
\hline p57 & Podocyte (nuclear) & Negative (peripheral podocytes only) & Kp10 & Cell Marque \\
\hline CD31 & Endothelial & Peripheral, focally central & JC70 & Cell Marque \\
\hline ERG & Endothelial (nuclear) & Peripheral, focally central & EPR3864 & Ventana \\
\hline GATA3 & Mesangial, distal tubules (nuclear) & Positive, subset & LSO823 & Biocare \\
\hline CD68 & Monocyte/macrophage & Positive, subset & KP-1 & Ventana \\
\hline CD20 & B-lymphocytes & No increase & L26 & Ventana \\
\hline CD3 & T-lymphocytes & No increase & 2GV6 & Ventana \\
\hline Ki-67 & Proliferating cells & No increase & $30-9$ & Ventana \\
\hline CMV & Cytomegalovirus & Negative & DDG9/CCH2 & Ventana \\
\hline Parvo & Parvovirus & Negative & & \\
\hline C4d & $\begin{array}{l}\text { Sites of complement activation, hyaline, } \\
\text { endothelial injury }\end{array}$ & N/A & Polyclonal & ALPCO/Biomedica \\
\hline
\end{tabular}

precluded recognition of thrombotic microangiopathy in other instances. Acute thrombotic microangiopathy was not significantly associated with time after transplant, patient age, calcineurin inhibitor exposure, irradiation, type of transplant (allogeneic versus autologous), or clinical GVHD in allogeneic recipients. Segmental glomerular basement membrane duplication was seen in three additional patients, consistent with chronic thrombotic microangiopathy.

C4d immunostaining was performed to visualize glomerular deposits in formalin-fixed, paraffinembedded tissue. With this method, we identified two cases (4\%) with granular capillary loop staining in the pattern of membranous nephropathy (Figures 3a-c). Silver staining also demonstrated small 
capillary wall lucencies (not shown). Membranous nephropathy occurred in male patients 61 and 64 years of age with peripheral blood allogeneic stem

Table 4 Glomerulitis in Nephrectomies: Average of Cell Counts in 25 Glomeruli (Excluding Segmental Cellular Lesions)

\begin{tabular}{lcccc}
\hline & Light microscopy (PAS) & CD3 & CD20 & CD68 \\
\hline $\begin{array}{l}\text { Transplant cases } \\
16\end{array}$ & 9.64 & & & \\
17 & 6.36 & 1.36 & 0.72 & 5.36 \\
& & 1.04 & 0.2 & 3.16 \\
Control cases & & & & \\
C-6 & 7.04 & 1.56 & 0.16 & 5.16 \\
C-7 & 4.08 & 0.76 & 0.04 & 1.6 \\
C-8 & 2.36 & 0.8 & 0.16 & 2.4 \\
\hline
\end{tabular}

Abbreviation: PAS, periodic acid schiff stain. cell transplant for myelodysplastic syndrome or T-prolymphocytic leukemia. Both had busulfan, fludarabine, and total body irradiation as conditioning, both had history of GVHD, and both had been treated with cyclosporine. Patient no. 23 was 2 years post-transplant, had an elevated serum creatinine of $1.7 \mathrm{mg} / \mathrm{dl}$ and serum albumin of $1.8 \mathrm{~g} / \mathrm{dl}$ (normal range $3.5-4.7 \mathrm{~g} / \mathrm{dl}$ ), along with spot urine protein of $100 \mathrm{mg} / \mathrm{dl}$ and hematuria, whereas patient no. 26 was 7 months post-transplant, had serum creatinine of $0.95 \mathrm{mg} / \mathrm{dl}$, serum albumin of $1.6 \mathrm{~g} / \mathrm{dl}$, spot urine protein of $237 \mathrm{mg} / \mathrm{dl}$, and urine protein to creatinine ratio of 2.15, with less C4d staining compared with patient no. 23. Neither glomerular nor renal disease was clinically suspected in either patient. Additional histologic findings in these two patients with membranous nephropathy included extensive interstitial fibrosis, mild-to-moderate arteriosclerosis, and

Table 5 Autopsy Cohort

\section{Clinical parameters \\ Patient age at autopsy \\ Time after transplant \\ Reason for transplant}

Type of transplant

Stem cell source

Conditioning with radiation

Calcineurin inhibitor exposure

Graft versus host disease

Serum creatinine

Histologic findings

Global glomerulosclerosis

Tubular atrophy

Interstitial inflammation

Arteriolar hyaline

Arteriosclerosis

C4d
Interstitial fibrosis

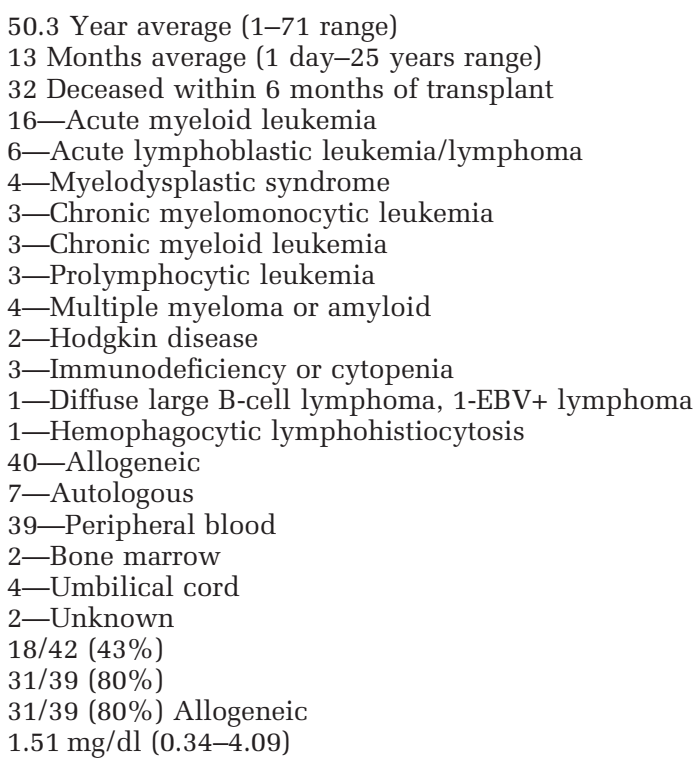

${ }^{\mathrm{a}}$ Membranous nephropathy and chronic thrombotic microangiopathy excluded. ${ }^{\mathrm{b}}$ Not directly matching histologic thrombotic microangiopathy. 
minimal-to-marked arteriolar hyalinosis (Figures 3b and c). C4d immunostaining also colocalized with hyaline in these and other patients. Flocculent or dense glomerular and arteriolar C4d staining was seen in rare glomeruli in patients with and without thrombotic microangiopathy (Figures $3 \mathrm{~b}$ and $\mathrm{c}$ and Table 5).

Other glomerular pathology included focal segmental glomerulosclerosis in patient no. 35, who died 2 months after an autologous hematopoietic cell transplant for myeloma, whereas patient no. 38 had evidence of diabetic nephropathy 13 years after an allogeneic peripheral blood hematopoietic cell transplant for chronic myeloid leukemia. Patient no. 64, who was 7 months post-allogeneic peripheral blood stem cell transplant for myelodysplastic syndrome, had distinctive fine black granules lining glomerular and some tubular basement membranes (Figure 3d), which were even apparent in the paraffin tissue kidney blocks but not in blocks from other organ systems. These did not have the characteristics of immune complex deposit, and were negative on calcium stain. Correlation with the patient history revealed ingestion of a homemade colloidal silver preparation, and a 'bluish-gray tint' to his skin. ${ }^{43,44}$ Electron microscopic examination of reprocessed formalin-fixed, paraffinembedded tissue demonstrated extremely dense small granules (Figure 3e), and energy-filtered transmission electron microscopy analysis was consistent with silver (argyria, Figure 3f). ${ }^{43,44}$ Given the nature of the lesions and intervals since transplantation, the glomerular pathology in these cases may not be related to hematopoietic cell transplant.

Non-glomerular infectious and neoplastic renal pathology (Figures $3 \mathrm{~g}$ and $\mathrm{h}$ ) included fungal invasion (patient no. 34, likely Candida sp.), bacterial thrombi (patient no. 61, who had known enterococcus and colitis), vascular amyloid (patient no. 59), and leukemia (patient no. 30, recurrent after autologous transplant). Otherwise, interstitial nephritis was scarce in hematopoietic cell transplant patients at autopsy; focal inflammation was seen in $17 / 47$ cases (36\%; Table 4$)$.

Although evaluation of renal tubules was hampered by autolysis in the majority of cases, three pediatric and two adult patients had evidence of acute tubular injury/necrosis, with either flattening or vacuolization of tubular epithelial cells (patient nos. 32, 36, 37, 51, and 59), all with elevated serum creatinine. Additionally, seven patients had evidence of sparse oxalate crystals within renal tubules (patient nos. 22, 25, 39, 54, 59, 62, and 64), as may be associated with acute tubular injury, since none of these patients had history of chronic kidney disease or oxalosis.

We also observed paucicellular interstitial fibrosis out of proportion to the degree of tubular atrophy in hematopoietic cell transplant kidneys. This pattern was seen in 22/47 (47\%) autopsy patients and showed no significant association with patient age, time after transplant, exposure to irradiation, alkylating agents, calcineurin inhibitors, type of transplant, or clinical GVHD.

Vascular pathology was frequent in hematopoietic cell transplant kidneys. At least moderate arteriosclerosis was noted in 27/47 cases (57\%). Patients with arteriosclerosis tended to be older (Figure 4), but arteriosclerosis did not appear to correlate with time after transplant or irradiation. Arteriolar hyaline was present in half of hematopoietic cell transplant kidneys $(25 / 47=53 \%)$, but was generally focal. The presence of hyaline was not correlated with patient age, calcineurin inhibitor exposure, irradiation, type of transplant, or time after transplant.

\section{Discussion}

We present our single-institution experience with renal pathology in hematopoietic cell transplant recipients, encompassing not only renal biopsy specimens for dysfunction but also patients without overt clinical renal impairment, including surgical resections for other causes and autopsy specimens. For the first time, we describe collapsing glomerulopathy, antiglomerular basement membrane disease, fibrillary glomerulonephritis, and distinctive but unique segmental cellular and sclerosing glomerular lesions in hematopoietic cell transplant recipients. We also found significant non-glomerular pathology in each group.

Focal segmental glomerulosclerosis has accounted for $\sim 6 \%$ of glomerular pathology in hematopoietic cell transplant, based on published reports. ${ }^{8,11,14,16,18,39,45}$ We encountered focal segmental glomerulosclerosis in 3 of 14 (21\%, patient nos. 6-8) patients with renal biopsy. Minimal change disease, also grouped with 'podocytopathies,' is relatively common in hematopoietic cell transplant,, 18 and was seen in 2 of 14 biopsied patients $(14 \%)$; however, to our knowledge, collapsing glomerulopathy has not been previously reported. Interestingly, the Caucasian adolescent boy with collapsing glomerulopathy achieved remission of proteinuria with immunosuppression, but upon proteinuria relapse was found to have focal segmental glomerulosclerosis of no special type. Outside of the study period, we recently encountered another pediatric hematopoietic cell transplant recipient with collapsing focal segmental glomerulosclerosis; this patient had a recent history of thrombotic microangiopathy, and prior exposure to both calcineurin inhibitors and sirolimus.

One hematopoietic cell transplant recipient in our series had antiglomerular basement membrane disease on biopsy. Antiglomerular basement membrane disease in the general population, especially with pulmonary and renal manifestations, has been associated with smoking or exposure to inhaled toxins; it is interesting that this patient had pulmonary GVHD clinically. Exposure of collagen-IV $\alpha-3$ epitopes as a result of immune-mediated lung injury is a speculative mechanism of antiglomerular 
basement membrane disease in this hematopoietic cell transplant recipient; however, antiglomerular basement membrane disease has not previously been reported in the hematopoietic cell transplant population, which makes this less likely. It is unclear whether the glomerulonephritis was related to the hematopoietic cell transplant, as it occurred more than 10 years after transplant.
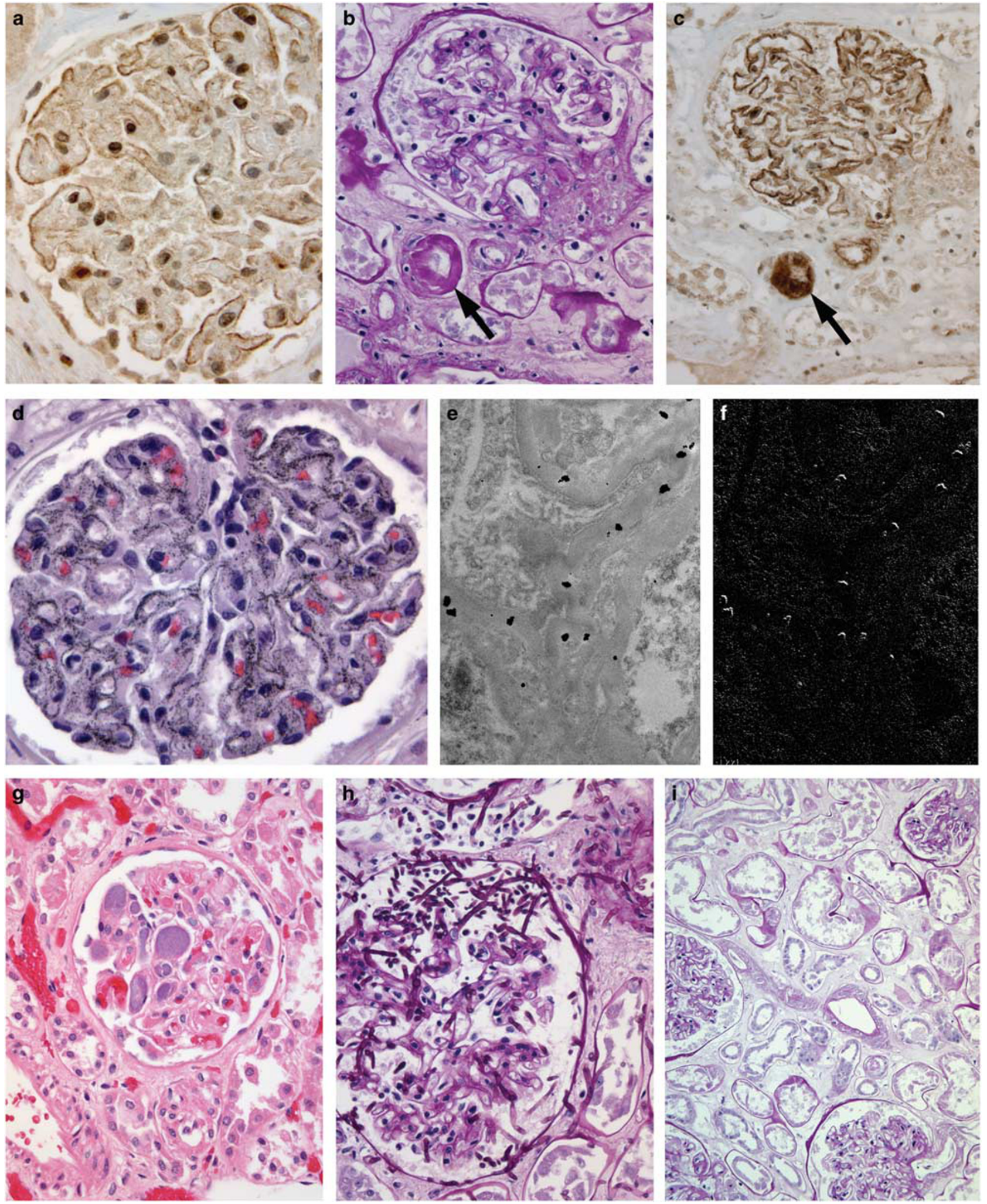
Fibrillary glomerulonephritis is characterized by immunoglobulin deposition in glomeruli, usually polyclonal, that forms deposits with organized substructure, generally randomly oriented fibrils of 10-30 nm diameter. Nasr et $a l^{46}$ has drawn association of fibrillary glomerulonephritis with malignancy (15/66 patients, $23 \%$ in their series), autoimmune disease $(10 / 66,15 \%)$, and other comorbidities, but to our knowledge, it has not been previously reported in the setting of hematopoietic cell transplantation. As this patient's proteinuria before transplant was noted to wax and wane with the course of his Hodgkin lymphoma, there was some concern for lymphoma recurrence after hematopoietic cell transplant. Yet, there was no evidence of malignancy for the year after biopsy, and proteinuria was partially controlled after a course of Rituximab treatment.

The group of patients who underwent kidney resection for malignancy $(n=5)$ or obstruction $(n=1)$ allowed 'incidental' analysis of non-neoplastic kidney 6-23 years after transplant in patients without overt renal dysfunction. All five of the patients with renal cell carcinoma had mesangial sclerosis, and two had peculiar cellular glomerular lesions unlike glomerulonephritides reported in native kidney biopsies of the non-hematopoietic cell transplant population, including those with renal cell carcinoma. By immunohistochemistry and electron microscopy, we identified endothelial, mesangial,

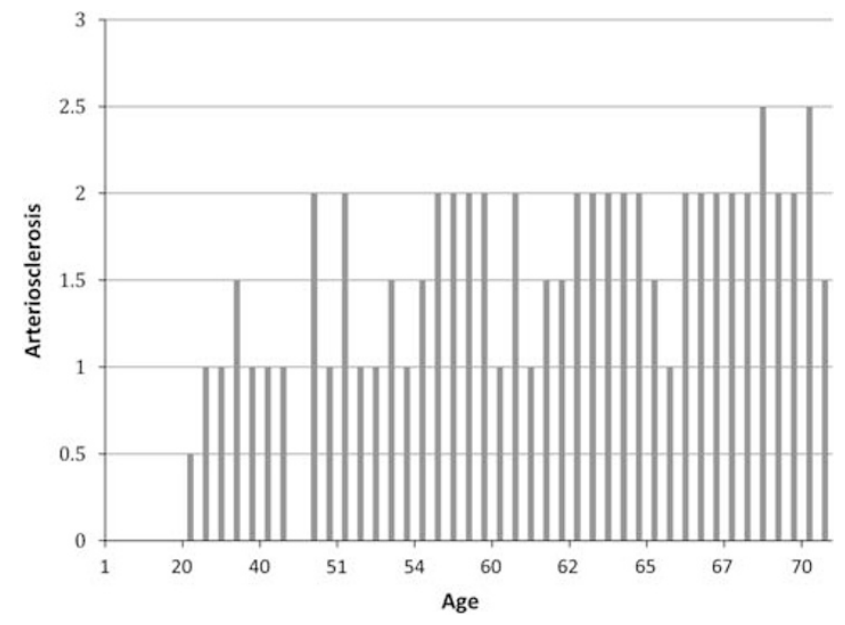

Figure 4 Patient age and arterial fibrosis score. and macrophage/monocytic cells in these segments, yet a subset of the cellular constituents remained unclassified. We hypothesize that chronic hematopoietic cell transplant-related injury over very long periods of time (11 and 22 years after transplant) contribute to this glomerular pathology. We suspect that such lesions have not been described in prior hematopoietic cell transplant biopsy series given their focality, association with little renal functional impairment, and long post-transplant time course as seen in our series; however, further study is certainly needed, with consideration for the potential interaction of hematopoietic cell transplant and renal cell carcinoma. These findings reinforce the necessity of non-neoplastic kidney assessment in cancer nephrectomies. ${ }^{47,48}$

We compared global glomerulosclerosis, interstitial fibrosis/tubular atrophy, arteriolar hyalinosis, and arteriosclerosis in the surgical hematopoietic cell transplant group with non-transplant patients with renal cell carcinoma under 55 years of age (otherwise unmatched). Global glomerulosclerosis was greater in the hematopoietic cell transplant group (average 26, or 25\% excluding patient with obstruction). Vascular pathology was prevalent in both groups, with the hematopoietic cell transplant group having seemingly more severe changes.

Our autopsy cohort afforded another view of renal pathology in patients unselected for renal dysfunction. We found acute thrombotic microangiopathy in $10(21 \%)$ of autopsy patient kidneys, although it was often only seen in rare glomeruli of the involved kidneys. Siami et $a l^{20}$ reported acute thrombotic microangiopathy in eight of a consecutive series of 20 hematopoietic cell transplant autopsies (40\%), while El-Seisi et $a l^{38}$ reported $12 / 26 \quad(46 \%)$ of transplant patients with acute thrombotic microangiopathy. A large study from the Fred Hutchinson Cancer Center (cohort transplanted 1992-1999) found acute thrombotic microangiopathy in $20 \%$ of 314 patients, with isolated thrombi in another $15 \% .{ }^{21}$ In their study, multivariate analysis identified acute GVHD, donor-recipient sex mismatch (female recipient/male donor), total body irradiation $>1200 \mathrm{cGy}$, and adenovirus infection associated with thrombotic microangiopathy. ${ }^{21}$ We did not identify significant clinical associations for thrombotic microangiopathy in our cohort, which was

Figure 3 Renal findings in hematopoietic cell transplant patients at autopsy. (a-c) Membranous nephropathy. (a) C4d immunohistochemical stain reveals fine granular capillary loop deposits, consistent with membranous nephropathy, patient no. 26. (b) PAS stain shows glomerular morphology in patient no. 23, also with membranous nephropathy. Note the interstitial fibrosis and prominent arteriolar hyaline at bottom right (arrow), and considerable interstitial fibrosis. (c) C4d stain in matched field from patient no. 23, showing prominent granular capillary loop staining, along with strong labeling of arteriolar hyaline (arrow). (d-f) Silver deposition, patient no. 64 . (d) Hematoxylin and eosin (H\&E) stain shows fine granular particles along capillary loops. (e) Electron microscopy of a glomerulus shows irregular size and shape of ultradense particles along basement membrane (reprocessed from formalin-fixed, paraffin-embedded tissue). (f) Corresponding energy-filtered transmission electron microscopy image showing the signal corresponding to silver. (g and h) Infectious findings. (g) Bacterial thrombi are present in numerous capillary loops of the glomerulus, patient no. 61. (h) Fungal hyphae surround glomerulus and vascular spaces at top on PAS stain, patient no. 34. (i) PAS stain demonstrates considerable interstitial widening without accompanying tubular atrophy, patient no. 39. There is considerable autolysis, but no interstitial inflammation. Original magnifications: 200x (i); 400x (b, c, g, and h); 630x (a and d); 14 800x (e and f). 
more limited by size, and lack of clinical information for many patients.

Several authors have suggested that interstitial inflammation and tubulitis could represent manifestations of GVHD in autopsy kidney. ${ }^{23,38,40}$ In their study of 26 autopsy cases, El-Seisi et $a 1^{38}$ noted substantial interstitial fibrosis, as we found in our group, but they also found tubulitis of unspecified degree in $67 \%$ of autopsied hematopoietic cell transplant patients, although they did not find an association of tubulitis with clinical GVHD. In a study of seven hematopoietic cell transplant patients with thrombotic microangiopathy, Mii et $a 1^{23}$ noted mild or moderate interstitial inflammation in all patients (two biopsy, five autopsy). We found inflammation in only $36 \%$ of autopsied kidneys, mostly quite mild (Table 5), although a greater proportion of patients biopsied for clinical indication in our series did have interstitial inflammation (9/14, 64\%; Table 1B). The reason for this difference in the autopsy cohorts is not apparent, although the transplantation eras were distinct (1992-2000 ElSeisi, versus majority of patients transplanted after 2005 in our study); nevertheless, interstitial nephritis was not a major finding in our autopsy group.

The utility and potential clinical implications of C4d staining in hematopoietic cell transplant kidney specimens has been a topic of recent interest. ${ }^{23,25,49}$ We used C4d as a surrogate marker of immune deposits and identified two hematopoietic cell transplant recipients with granular capillary loop deposition, consistent with occult membranous nephropathy. In separate studies, Mii et al, ${ }^{23,49}$ Laskin et $a{ }^{25}$ and Sakamoto et a ${ }^{50}$ demonstrated C4d labeling in arterioles and glomeruli of biopsy and autopsy kidney specimens from patients with hematopoietic cell transplant and thrombotic microangiopathy. Mii et al ${ }^{23,49}$ surmised that this finding might provide evidence of antibodymediated pathology, based on analogy with antibody mediation rejection in solid organ transplantation. ${ }^{49}$ Subsequently, Laskin et $a l^{25}$ found arteriolar but not glomerular C4d staining to correlate with histologic thrombotic microangiopathy in patients with both allogeneic and autologous hematopoietic cell transplant. However, neither study included a nonhematopoietic cell transplant thrombotic microangiopathy control group. We observed flocculent, poorly localized staining in rare glomeruli in 28/43 $(65 \%)$ of hematopoietic cell transplant recipients, including those with and without thrombotic microangiopathy. We also noted C4d staining in arterioles, often in a pattern corresponding to arteriolar hyalinosis (Figures $3 \mathrm{~b}$ and $\mathrm{c}$ ). Other studies and our unpublished observations have identified glomerular C4d reactivity in biopsies with thrombotic microangiopathy or endothelial injury in a variety of clinicopathologic settings, such as lupus-associated thrombotic microangiopathy, hemolytic uremia syndrome, atypical hemolytic uremia syndrome, and allograft glomerulopathy. ${ }^{51-53}$ It remains possible that the observed C4d reactivity could represent nonspecific insudative C-4 accumulation (similar to C3 and IgM in focal segmental glomerulosclerosis and/or hyaline), or complement pathway activation.

In summary, we report renal pathologic findings in contemporary series of renal biopsies, surgical specimens, and autopsy kidneys of hematopoietic cell transplant recipients $(n=67)$. We describe for the first time in this setting collapsing glomerulopathy, fibrillary glomerulonephritis, antiglomerular basement membrane disease, and peculiar segmental cellular glomerular lesions present in 2/5 hematopoietic cell transplant patients with renal cell carcinoma. As expected, thrombotic microangiopathy was prevalent in hematopoietic cell transplant patients; further, C4d immunohistochemical staining was used to uncover membranous nephropathy in two autopsy patients. Many patients had multiple renal abnormalities, including tubulointerstitial and vascular pathology, along with glomerular changes.

\section{Acknowledgments}

We wish to acknowledge the expert assistance of Robert Kayton and Chris Arthur with electron microscopy and energy-filtered transmission electron microscopy analysis. Energy-filtered transmission electron microscopy was performed at the Multiscale Microscopy Core with technical support from the Oregon Health \& Science University-FEI Living Lab and the Oregon Health \& Science University Center for Spatial Systems Biomedicine. Linh Matsumura performed the histochemical and immunohistochemical staining. Dr Terry Morgan assisted with statistical analysis. A subset of data was presented at the United States and Canadian Academy of Pathologists annual meeting on 3 March 2014 (biopsy and surgical cohorts with biopsy cases incorporated into a literature meta-analysis, reference no. 8), and is accepted for presentation on 15 March 2016 (autopsy cohort).

\section{Disclosure/conflict of interest}

The authors declare no conflict of interest.

\section{References}

1 Gajewski JL, Ippoliti C, Ma Y et al. Blood and marrow transplantation. In: Snyder E (ed). Rossi's Principles of Transfusion Medicine, 3rd edn. Lippincott Williams \& Wilkins: Philadelphia, PA, 2002, pp 555-569.

2 Copelan EA. Hematopoietic stem-cell transplantation. N Engl J Med 2006;354:1813-1826.

3 Li HW, Sykes M. Emerging concepts in haematopoietic cell transplantation. Nat Rev Immunol 2012;12: 403-416.

4 Kambham N, Higgins JP, Sundram U et al. Hematopoietic stem cell transplantation: graft versus host 
disease and pathology of gastrointestinal tract, liver, lung. Adv Anat Pathol 2014;21:301-320.

5 Schrier RW, Parikh CR. Comparison of renal injury in myeloablative autologous, myeloablative allogeneic and nonmyeloablative allogeneic haematopoietic cell transplantation. Nephrol Dial Transplant 2005;20: 678-683.

6 Singh N, McNeely J, Parikh S et al. Kidney complications of hematopoietic stem cell transplantation. Am J Kidney Dis 2013;61:809-821.

7 Parikh CR, Coca SG. Acute renal failure in hematopoietic cell transplantation. Kidney Int 2006;69:430-435.

8 Troxell ML, Higgins JP, Kambham N. Renal pathology associated with hematopoietic stem cell transplantation. Adv Anat Pathol 2014;21:330-340.

9 Hingorani S, Guthrie KA, Schoch G et al. Chronic kidney disease in long-term survivors of hematopoietic cell transplant. Bone Marrow Transplant 2007;39: 223-229.

10 Srinivasan R, Balow JE, Sabnis S et al. Nephrotic syndrome: an under-recognised immune-mediated complication of nonmyeloablative allogeneic haematopoietic cell transplantation. Br J Haematol 2005;131: 74-79.

11 Brukamp K, Doyle AM, Bloom RD et al. Nephrotic syndrome after hematopoietic cell transplantation: do glomerular lesions represent renal graft-versus-host disease? Clin J Am Soc Nephrol 2006;1:685-694.

12 Reddy P, Johnson K, Uberti JP et al. Nephrotic syndrome associated with chronic graft-versus-host disease after allogeneic hematopoietic stem cell transplantation. Bone Marrow Transplant 2006;38:351-357.

13 Colombo AA, Rusconi C, Esposito C et al. Nephrotic syndrome after allogeneic hematopoietic stem cell transplantation as a late complication of chronic graftversus-host disease. Transplantation 2006;81:1087-1092.

14 Chang A, Hingorani S, Kowalewska J et al. Spectrum of renal pathology in hematopoietic cell transplantation: a series of 20 patients and review of the literature. Clin J Am Soc Nephrol 2007;2:1014-1023.

15 Kemper MJ, Gungor T, Halter J et al. Favorable longterm outcome of nephrotic syndrome after allogeneic hematopoietic stem cell transplantation. Clin Nephrol 2007;67:5-11.

16 Troxell ML, Pilapil M, Miklos DB et al. Renal pathology in hematopoietic cell transplantation recipients. Mod Pathol 2008;21:396-406.

17 Chan GS, Lam MF, Au WY et al. Clinicopathologic analysis of renal biopsies after haematopoietic stem cell transplantation. Nephrology (Carlton) 2008;13: 322-330.

$18 \mathrm{Hu}$ SL. The role of graft-versus-host disease in haematopoietic cell transplantation-associated glomerular disease. Nephrol Dial Transplant 2011;26:2025-2031.

19 Terrier B, Delmas Y, Hummel A et al. Post-allogeneic haematopoietic stem cell transplantation membranous nephropathy: clinical presentation, outcome and pathogenic aspects. Nephrol Dial Transplant 2007;22: 1369-1376.

20 Siami K, Kojouri K, Swisher KK et al. Thrombotic microangiopathy after allogeneic hematopoietic stem cell transplantation: an autopsy study. Transplantation 2008;85:22-28.

21 Changsirikulchai S, Myerson D, Guthrie KA et al. Renal thrombotic microangiopathy after hematopoietic cell transplant: role of GVHD in pathogenesis. Clin J Am Soc Nephrol 2009;4:345-353.
22 Glezerman IG, Jhaveri KD, Watson TH et al. Chronic kidney disease, thrombotic microangiopathy, and hypertension following $\mathrm{T}$ cell-depleted hematopoietic stem cell transplantation. Biol Blood Marrow Transplant 2010;16:976-984.

23 Mii A, Shimizu A, Kaneko T et al. Renal thrombotic microangiopathy associated with chronic graft-versushost disease after allogeneic hematopoietic stem cell transplantation. Pathol Int 2011;61:518-527.

24 Jodele S, Licht C, Goebel J et al. Abnormalities in the alternative pathway of complement in children with hematopoietic stem cell transplant-associated thrombotic microangiopathy. Blood 2013;122:2003-2007.

25 Laskin BL, Maisel J, Goebel J et al. Renal arteriolar C4d deposition: a novel characteristic of hematopoietic stem cell transplantation-associated thrombotic microangiopathy. Transplantation 2013;96:217-223.

26 Sakarcan A, Neuberg RW, McRedmond KP et al. Membranoproliferative glomerulonephritis develops in a child with autologous stem cell transplant. Am J Kidney Dis 2002;40:E19.

27 Kim JY, Lee MY, Kim B et al. Membranoproliferative glomerulonephritis following allogeneic hematopoietic stem cell transplantation. Clin Exp Nephrol 2010;14: 630-632.

28 Imai H, Oyama Y, Miura AB et al. Hematopoietic cell transplantation-related nephropathy in Japan. Am J Kidney Dis. 2000;36:474-480.

29 Nouri-Majelan N, Sanadgol H, Ghafari A et al. Antineutrophil cytoplasmic antibody-associated glomerulonephritis in chronic graft-versus-host disease after allogenic hematopoietic stem cell transplantation. Transplant Proc 2005;37:3213-3215.

30 Suehiro T, Masutani K, Yokoyama M et al. Diffuse proliferative glomerulonephritis after bone marrow transplantation. Clin Nephrol 2002;58:231-237.

31 Forslund $\mathrm{T}$, Anttinen J, Hallman $\mathrm{H}$ et al. Mesangial proliferative glomerulonephritis after autologous stem cell transplantation. Am J Kidney Dis 2006;48:314-320.

32 Takeuchi M, Tamaoki A, Tada A et al. Crescentic glomerulonephritis developing 3 months after autologous peripheral blood stem cell transplantation for non-Hodgkin's lymphoma. Bone Marrow Transplant 1998;22:725-727.

33 Kingdon EJ, Johnston RE, Pawson R et al. ANCA +ve vasculitis after autologous PBSC transplantation. Nephrol Dial Transplant 2002;17:285-287.

34 Kimura S, Horie A, Hiki Y et al. Nephrotic syndrome with crescent formation and massive IgA deposition following allogeneic bone marrow transplantation for natural killer cell leukemia/lymphoma. Blood 2003;101:4219-4221.

35 Navaneethan SD, Taylor J, Goldman B et al. Antineutrophil cytoplasmic antibody associated crescentic IgA nephropathy in hematopoietic stem cell transplantation. Clin Nephrol 2009;71:59-62.

36 Chan GS, Lam MF, Au WY et al. IgA nephropathy complicating graft-versus-host disease, another nephropathy causing nephrotic syndrome after bone marrow transplantation. Histopathology 2004;45:648-651.

$37 \mathrm{Hu}$ SL, Colvin GA, Rifai A et al. Glomerulonephritis after hematopoietic cell transplantation: IgA nephropathy with increased excretion of galactose-deficient IgA1. Nephrol Dial Transplant 2010;25:1708-1713.

38 El-Seisi S, Gupta R, Clase CM et al. Renal pathology at autopsy in patients who died after hematopoietic stem cell transplantation. Biol Blood Marrow Transplant 2003;9:683-688. 
39 Schwarz A, Haller H, Schmitt R et al. Biopsy-diagnosed renal disease in patients after transplantation of other organs and tissues. Am J Transplant 2010;10: 2017-2025.

40 Kusumi E, Kami M, Hara S et al. Postmortem examination of the kidney in allogeneic hematopoietic stem cell transplantation recipients: possible involvement of graft-versus host disease. Int J Hematol 2008;87: 225-230.

41 Barrett CM, Larsen CP, Houghton DC et al. Membranous glomerulonephritis with crescents. Int Urol Nephrol 2014;46:963-971.

42 Troxell ML, Weintraub LA, Higgins JP et al. Comparison of C4d immunostaining methods in renal allograft biopsies. Clin J Am Soc Nephrol 2006;1:583-591.

43 Mayr M, Kim J, Wanner D et al. Argyria and decreased kidney function: are silver compounds toxic to the kidney?. Am J Kid Dis 2009;53:890-894.

44 Colvin RB. Argyria. In: Colvin RB (ed). Diagnostic Pathology: Kidney Diseases, Vol. 4, 1st edn. Amirsys: Manitoba, CA, USA, 2011, pp 80-81.

45 Fofi C, Barberi S, Stoppacciaro A et al. Focal segmental glomerulosclerosis as a complication of graft-versushost disease. Nat Rev Nephrol 2009;5:236-240.

46 Nasr SH, Valeri AM, Cornell LD et al. Fibrillary glomerulonephritis: a report of 66 cases from a single institution. Clin J Am Soc Nephrol 2011;6:775-784.
47 Bijol V, Mendez GP, Hurwitz S et al. Evaluation of the nonneoplastic pathology in tumor nephrectomy specimens: predicting the risk of progressive renal failure. Am J Surg Pathol 2006;30:575-584.

48 Henriksen KJ, Meehan SM, Chang A. Non-neoplastic renal diseases are often unrecognized in adult tumor nephrectomy specimens: a review of 246 cases. Am J Surg Pathol 2007;31:1703-1708.

49 Mii A, Shimizu A, Masuda Y et al. Renal thrombotic microangiopathy associated with chronic humoral graft versus host disease after hematopoietic stem cell transplantation. Pathol Int 2011;61:34-41.

50 Sakamoto K, Imamura T, Osone S et al. Hematopoietic stem cell transplantation-associated thrombotic microangiopathy accompanied by renal arteriolar C4d deposition. Pediatr Transplant 2015;19:E97-100.

51 Cohen D, Koopmans M, Kremer Hovinga IC et al. Potential for glomerular C4d as an indicator of thrombotic microangiopathy in lupus nephritis. Arthritis Rheum 2008;58:2460-2469.

52 Chua JS, Baelde HJ, Zandbergen $\mathrm{M}$ et al. Complement factor C4d is a common denominator in thrombotic microangiopathy. J Am Soc Nephrol 2015;26:2239-2247.

53 Chua JS, Gasim A, Wolterbeek R et al. Glomerular complement factor C4d marks glomerular basement membrane duplications: C4d beyond antibody induced injury. J Am Soc Nephrol 2015;26 (Suppl.): 245A.

Supplementary Information accompanies the paper on Modern Pathology website (http://www.nature.com/ modpathol) 